\title{
Coaching and training as influential factor, affecting sport at universities level
}

\author{
Syed Zia-Ul-Islam ${ }^{\mathrm{ABCDE}}$, Salahuddin Khan ${ }^{\mathrm{ACD}}$, Alamgir Khan ${ }^{\mathrm{ABD}}$, Samiullah Khan ${ }^{\mathrm{CD}}$ \\ Department of Sports Sciences and Physical Education Gomal University D.I.Khan, Pakistan
}

Authors' Contribution: A - Study design; B - Data collection; C - Statistical analysis; D - Manuscript preparation; E - Funds collection.

$\begin{array}{ll}\text { Abstract } & \\ \text { Purpose: } & \text { In Pakistan, the performance of the university athletes is not satisfactory with reference to preparedness } \\ & \text { for such kind of athletes to compete in international level. Therefore, this study intends to focus upon } \\ & \text { the role of proper coaching and training as factor in the production and preparedness of university } \\ & \text { level athletes to participate at international level sports. The main purpose of the current study was } \\ & \text { to investigate the existence of coaching and training as factor influencing sport participation and } \\ & \text { performance of the athletes at universities level. } \\ & \text { The total } 671 \text { athletes and } 31 \text { director sports were selected from both public and private sector universities } \\ & \text { as sample through random sampling technique. Data was collected through Self-administered, Likert } \\ \text { Material: } & \text { type questionnaire. } \\ & \text { Our results revealed that improper coaching and training affect sport performance of the athletes both } \\ & \text { in public and in private sector universities. Furthermore, the influence of coaching and training were } \\ & \text { found more at private sector universities in comparison with public sector universities. Also, there were } \\ \text { Results: } & \text { no significant gender-wise (male, female) as well as category-wise (director sports, athletes) responsive } \\ & \text { differences were observed. } \\ & \text { It was concluded that improper coaching and deficit facilities, lack of responsible coaching, negative } \\ & \text { reinforcement and unavailability of trained coaches negatively affect the sports performance of athletes. } \\ \text { Conclusions: } & \text { In addition, insulting, shouting, verbal abusing of coaches and trainers, as well as discrimination and } \\ & \text { nepotism hinder sports activities at universities. } \\ & \text { coaching, training, athletes. university, public, private. sport, athletes. }\end{array}$

\section{Introduction}

Sport is considered one of the significant components of the educational institutions due to its vitality with reference to the overall development of an individual. Apart from the personal benefits, sport also has the quality to portray the excellent picture of the country in the world by achieving healthier position in sport activities. The athletes who performed excellent in sport are considered as a symbol for their country. Therefore, preparation and production of the first-class athletes is need of the day for every country in the world. Worldwide, most of the countries provide all the essential sports facilities to the students in educational institutions, because educational institutions are the place to produce and better train their athletes. Knapp [1] confirms that from 2004 to 2012 Olympics, most of the athletes who won medals were university students. To obtain outstanding result in sport activities, provision of all the required facilities is essential for student's athletes in educational institutions especially at university level. These facilities may include provision of the proper sports gear, availability of the proper space for the event with safety measures/first aid facilities, qualified staff, proper training, and provision/ positive attitude of coaching staff etc. Deficiencies in the required sports facilities create hurdles in smooth functioning of sport organizations. Coaching and training facilities may play the role of central hub for the better

\footnotetext{
(C) Syed Zia-Ul-Islam, Salahuddin Khan, Alamgir Khan,

Samiullah Khan, 2019
}

doi:10.15561/18189172.2019.0306 performance in sport among all the needed facilities for better performance. Poor coaching and training restrict the performance of the athletes in the shape of their skill, occurrence of injuries, poor strategies, and lack of coordination among team members, and fragile psyche etc. which leads toward failure, or poor performance in sports competitions. Deficiency in all types of required facilities may work as limiting factor that negatively affects the performance of athletes. Coach with positive and good behaviors plays a main role in the promotion of sport. A negative and unfavorable behavior of a coach badly influences the performance of the athletes. According to Kenow and Williams [2] described the vitality of the coach's experience towards the effectiveness of the athlete's performance. The authors further stated that experience of coach can successfully lead the athletes towards achieving their targets. Amorose and AndersonButcher [3] stated that coaches have either supportive behavior or controlled, always plays a positive role in the promotion of sport performance among the athletes. While, controlled behavior of the coach mostly influences the athletes' sport performance negatively. Amorose and Horn [4] stated that behavior of coaches depends on their communication skill, positive response, and social support; these qualities of coach are highly correlated with satisfaction of the athletes and provide a firm base to improve the performance of their athletes according to the acquired level. Bruner, Hall [5] indicated that coach plays a significant role in the sporting life of young athletes as they have the potential to affect the athletes sporting 
experiences positively or negatively. According to Leite, Coelho [6] in the initial and developmental stages, some of the less experience coaches can refine the performance of the young athletes. The authors further stated that in initial stage many of young athletes are more sensitive in learning to develop their physique, techniques, strategic qualities, and psychological abilities. Cushion, Armour [7] concluded that coach with good and positive experience always a plays a key role in the initial and developmental stage of athletes; it may contribute the quality development, strengthen, and lengthen the career of the athletes in the future. Cushion, Armour [7] indicated that coaches are required to educate themselves and get a hold on skills for the proper guidance of the athletes with the help of refresher courses for coaching and particularly the experience acquired to participate in sport competitions as a coach or as an athlete. Serrano, Shahidian [8] checked the hypothesis in their research study that "less experienced coaches possess appropriate knowledge to lead and develop proper sport development of the young players" it appears that the education process of coach i.e. training courses, gaining of experience from the participation in sport events as a competitor or as a coach can help to eradicate all those factors responsible for lowering sport performance.

Hypotheses: coaching and training is existing as factor and significantly affect sport both in public and private sector universities, there is no significant difference between the perception of public and private sector universities respondents regarding the effect of coaching and training as factor upon sport, there is no gender wise and category wise (athletes and director) significant difference regarding the effect coaching and training as factor upon sport.

Objectives: to investigate the existence and negative affect of coaching and training upon university sport both in public and in private sector universities of KP, Pakistan, to check the difference between the perception of public and private sector universities respondents regarding the effect of coaching and training as factor upon sport performance of the athletes, to measure the difference in responses gender wise (male and female) and category wise (athletes and director sport) regarding the influence of coaching and training upon sport performance of the athletes both in public and in private sector universities.

\section{Material and Methods}

Participants: The director's sport and athletes of public and private sector universities of KP, Pakistan was preferred as population. The total 31 universities are placed in KP, Pakistan in which 21 were in the public and 10 in the private sector respectively. The total number of the athletes was 3305 (864 private +2472 public) after inclusion the 31 director sport the sum of the population was 3336 . To confirm the sample size, the researcher followed L. R. Gay suggestion and took $20 \%$ sample from both types of universities. To pick the representative sample the researcher used proportionate random sampling technique. The total 671 athletes and 31 director sports were selected as sample from public and in private sector universities of KP, Pakistan.

Procedure: The survey method was adopted for data collection. A Likert type interval scale was prepared containing of five options from strongly agrees to strongly disagree having score of 5 to 1 respectively. the content validity pilot testing and reliability of the self-developed questionnaire were performed accordingly. The prepared questionnaire was personally distributed among the selected population of each university athletes. The filled questionnaires were collected back. The $82 \%$ returned response was recorded.

Statistics analyses: Simple linear regression, ANOVA and t-test were applied with help of SPSS version 24 to test the formulated hypotheses of the current research study for statistical analyses.

\section{Results}

The table 1 reveals that coaching and training ( $M=$ $4.10, S D=.565, n=573$ ) is significantly exist as a factor influencing sport performance among university's athletes in both type (public and private) Universities of KP, Pakistan $\chi 2=267.798$, Asymp. Sig. $=.000<\alpha=.05$. Therefore, hypothesis 1 is hereby accepted.

The table 2 indicates that influence of coaching and

Table 1. Shows the existence of Coaching and Training as a Factor Influencing Sports both in Public and Private sector Universities

\begin{tabular}{llllllll}
\hline Testing Variable & N & Mean & Std. Deviation & Minimum & Maximum & Chi-Square Asymp. Sig. \\
\hline Coaching and Training & 573 & 4.10 & .565 & 2.47 & 5.00 & 267.798 & .000 \\
\hline
\end{tabular}

$\alpha=0.05$ (accepted)

Table 2.Shows the Influence of Coaching and Training as a Factor upon Public sector Universities

\begin{tabular}{llllllll}
\hline Predictor & Criterion & $\mathbf{R}$ & $\mathbf{R}$ Square & $\begin{array}{l}\text { Adjusted } \mathbf{R} \\
\text { Square }\end{array}$ & $\begin{array}{l}\mathbf{F} \\
\mathbf{( d f = 1 , 4 1 1 )}\end{array}$ & $\begin{array}{l}\mathbf{T} \\
(\mathbf{d f =} \mathbf{4 1 1})\end{array}$ & $\mathbf{B}$ \\
\hline $\begin{array}{l}\text { coaching and } \\
\text { training }\end{array}$ & $\begin{array}{l}\text { Public sector } \\
\begin{array}{l}\text { University } \\
\text { Sports }\end{array}\end{array}$ & .531 & .282 & .280 & $\begin{array}{l}161.075 \\
\text { (Sig.=.000) }\end{array}$ & $\begin{array}{l}16.842 \\
\text { (Sig.=.000) }\end{array}$ & .531 \\
\hline
\end{tabular}

$\alpha=.05$ (accepted) 
training as factor upon the sports performance of athletes in public sector universities is .282 (28\%). The Coaching and Training significantly predicted university sports $\mathrm{B}=$ $.531, \mathrm{t}(411)=16.842$, Sig. $=.000<\alpha=.05$. The Table also explains that a significant proportion of variance occurred in sports performance among the public sector university's athletes due effect of Coaching and Training as factor $\mathrm{f}(1,411)=161.075$, Sig. $=.000<\alpha=.05$. The table also indicates that if one unit increases in Coaching and Training (predictor) will cause of .531-unit increase in university sports (Criterion) among the athletes of public sector universities. Hence the above mentioned hypothesis is hereby accepted.

The table 3 explains that influence of coaching and training as factor upon university sport performance among athletes is $.535(53 \%)$ in private sector universities of KP, Pakistan. The coaching and training as factor significantly predicted sport performance among private university's athletes $\mathrm{B}=.732, \mathrm{t}(158)=13.488$, Sig. $=.000$ $<\alpha=.05$. The Table 3 also depicted that a significant proportion of variance occurred in university's athletes sport performance due coaching and training as factor $\mathrm{f}$ $(1,158)=181.926$, Sig. $=.000<\alpha=.05$. The table also indicates that if one unit increases in coaching and training as factor (predictor) will cause of .732 unit increases in university's sports performance (Criterion) among the athletes of private sector universities. Therefore, the hypothesis 3 is hereby accepted.

The Table 4 expresses that public sector universities respondents $(M=4.008, S D=.547, n=413)$ and private sector universities respondents $(M=4.355, S D=.537$, $n=160), \mathrm{t}(\mathrm{df}=571)=-4.645$, Sig. $=.414>\alpha=.05$. The data revealed that no significant difference was found between the mean of public and private sector university's respondents regarding the influence of Coaching and Training as factor upon the sports performance of the university's athletes in the province of KP, Pakistan. Hence the hypothesis 4 is hereby accepted.

The Table 5 shows the male $(M=4.095, S D=.568$, $n=454)$ and female $(M=4.141, S D=.555, n=118), \mathrm{t}$ $(\mathrm{df}=570)=-.788$, Sig. $=.841>\alpha=.05$. The above data portrays that male and female respondents in both type of universities have the same mean and have no significant difference were found among their views regarding the effect of coaching and training as factor upon the sport upon the performance of athletes at university level. The tested hypothesis hereby accepted.

The Table 6 demonstrates the athletes $(M=4.10, S D=$

Table 3. Shows the Influence of Coaching and Training as a Factor upon Private sector Universities Sports

\begin{tabular}{llllllll}
\hline Predictor & Criterion & $\mathbf{R}$ & $\begin{array}{l}\mathbf{R} \\
\text { Square }\end{array}$ & $\begin{array}{l}\text { Adjusted } \mathbf{R} \\
\text { Square }\end{array}$ & $\begin{array}{l}\mathbf{F} \\
\text { (df= 1, 158) }\end{array}$ & $\begin{array}{l}\mathbf{T} \\
\text { (df= 158) }\end{array}$ & $\mathbf{B}$ \\
\hline $\begin{array}{l}\text { Coaching } \\
\text { and training } \begin{array}{l}\text { Pnivate sector } \\
\text { Sports }\end{array}\end{array}$ & .732 & .535 & .532 & $\begin{array}{l}181.926 \\
\text { (Sig.=.000) }\end{array}$ & $\begin{array}{l}13.488 \\
\text { (Sig.=.000) }\end{array}$ & .732 \\
\hline
\end{tabular}

$\alpha=0.05$ (accepted)

Table 4. Showing mean difference between the perception of public and private sector universities respondents regarding the effect of Coaching and training as factor upon sport performance of the athletes in KP, Pakistan

\begin{tabular}{|c|c|c|c|c|c|c|c|}
\hline Testing Variable & University type & $\mathbf{N}$ & Mean & Std. Deviation & Df & $\mathbf{T}$ & $\mathbf{P}$ \\
\hline Mean of Coaching and & Public Sector Universities & 413 & 4.008 & .547 & \multirow{2}{*}{571} & \multirow{2}{*}{-4.645} & \multirow{2}{*}{.414} \\
\hline Training & Private Sector Universities & 160 & 4.355 & .537 & & & \\
\hline
\end{tabular}

$\alpha=0.05$ (accepted)

Table 5. Showing Gender wise (Male \& Female) difference regarding the effect Coaching and training as factor upon sport performance of the athletes both public and private sector universities of KP, Pakistan.

\begin{tabular}{llllllll}
\hline Testing Variable & Gender & $\mathbf{N}$ & Mean & Std. Deviation & Df & T & $\mathbf{P}$ \\
\hline \multirow{2}{*}{ Mean of coaching and training } & Male & 454 & 4.095 & .568 & \multirow{2}{*}{570} & \multirow{2}{*}{-.788} & \multirow{2}{*}{.841} \\
\hline
\end{tabular}

$\alpha=0.05$ (accepted)

Table 6. Showing difference between responses of athletes and director sport regarding the effect of Coaching and training as factor upon sport performance of the athletes both in public and in private sector universities of KP, Pakistan.

\begin{tabular}{llllllll}
\hline Testing Variable & Category & $\mathbf{N}$ & Mean & Std. Deviation & Df & T & P \\
\hline \multirow{2}{*}{ Mean of coaching and training } & Athletes & 546 & 4.10 & .563 & \multirow{2}{*}{571} & \multirow{2}{*}{-1.103} & \multirow{2}{*}{.666} \\
& Director Sports & 27 & 4.22 & .597 & & & \\
\hline
\end{tabular}

$\alpha=0.05$ (accepted) 
.563, $n=546)$ and director Sport $(M=4.22, S D=.597, n=$ $27), \mathrm{t}(\mathrm{df}=571)=-1.103$, Sig. $=.666>\alpha=.05$. The figures show that no significant difference is notice between the view point of athletes and director sport regarding the effect of coaching and training as factor upon the sport performance of athletes both in public and private sector universities. Hypothesis 6 is hereby accepted.

\section{Discussion}

The results of the current research study issuers, that improper coaching, and training facilities as influential factors existed in universities and significantly affect sport both in public and in private sector universities.

In the same circumstances Moen [9] found in his study titled "coach-athlete relationship and expectations" that democratic coach behavior was the most predictable. The author also argued that a large number coaches and athletes perceived that coach's democratic behaviors have a significant impact on athlete's performance. Similarly, negative attitude of the coaches adversely affects the performance of athletes.

Smoll, Cumming [10] indicated that the role of coach in polishing the skills and technique of athletes are highly effective regarding the relationship between coaches and parents Turman [11] found that acts of the coaches like unfairness, uneasiness, and ridicule affect the cohesion among the team players.

Côté, Young [12] also claimed that sports participation among students in any institution can be increase by the coaches through positive role play. The author further stated that coaches should have to suggest beneficial opportunities to athletes like fun, pleasure, psychological satisfaction, confidence, and self-respect to the athletes This represents a massage that the role of the coach and trainer in adequate training should not be ignored in the field of sport. In this circumstance Roxas and Ridinger [13] found that There is a great relationship between the behavior of the coach and the performance of the athlete. The authors found that various athletic outcomes included anxiety, fatigue, self-confidence, and willingness to cheat to win. He claimed that The coach's positive behavior gives positive and fruitful results, while the coach's negative behavior has been related with negative results.

Mottaghi, Atarodi [14] also confirmed the result of the present research study and stated that coaches, athletes, and official have the competitive emergencies like anxiety,

\section{References}

1. Knapp D. The case for university sport. 2011.

2. Kenow L, Williams JM. Coach-athlete compatibility and athlete's perception of coaching behaviors. Journal of Sport Behavior. 1999;22(2):251-260.

3. Amorose AJ, Anderson-Butcher D. Exploring the independent and interactive effects of autonomysupportive and controlling coaching behaviors on adolescent athletes' motivation for sport. Sport, Exercise, and Performance Psychology. 2015;4(3): 206-212. https://doi.org/10.1037/spy0000038

4. Amorose AJ, Horn TS. Pre-to post-season changes in the intrinsic motivation of first year college athletes: stress etc. between athletes before the competition and after completion are linked to the planning and training of their coaches. Serrano, Shahidian [8] found that ideally experienced trainers have the knowledge and improves young sports persons and their sports performance, which related with the result of current research study.

Siekańska [15] established in his study that the liberality of trainers with the athletes can make the athletes to perform better in sports competitions. The inappropriate coaching and training affect mentally the athlete who turns to low efficiency [16-20]. Mostly the above mentioned studies supported the results of the present research study.

\section{Conclusion}

On the bases of analyses and findings it was concluded that negative effects of coaching and training exist in both public and private sector universities hindering the sports participation and performance of the athletes. The results indicate that no differences were found among the responses of director sports and athletes (male female) regarding the negative affect of coaching and training upon the performance and participation the universities athletes. However, the results indicate that more negative affect was reported in private sector universities as compare to public sector universities. The factors behind the negative affect of coaching and training upon athlete's participation and poor performance in sports activities at university level are improper coaching and training facilities, negative attitude of the coach, negative role of coach regarding tackling the social problems of the player, lack of the sense of responsibility on part of coaches and negative reinforcement. Likewise, the other factors that may hinder the performance includes untrained coaches, insulting, shouting, verbal abusing of coach and trainer, discrimination and nepotism of the coach and trainer and poor contact of the coaches with athlete's parents affect the participation level of the athlete in sport at university level. The concern authority may focus upon the above element of coaching to enable the university level athletes to compete at national and international sport competitions.

\section{Conflict of interest}

The author declares that there is no conflict of interest.

Relationships with coaching behavior and scholarship status. Journal of Applied Sport Psychology. 2001;13(4):355- 73. https://doi.org/10.1080/104132001753226247

5. Bruner MW, Hall J, Côté J. Influence of sport type and interdependence on the developmental experiences of youth male athletes. European Journal of Sport Science. 2011;11(2):131- 42. https://doi.org/10.1080/17461391.2010.499969

6. Leite N, Coelho E, Sampaio J. Assessing the importance given by basketball coaches to training contents. Journal of human kinetics. 2011;30:123- -33. https://doi.org/10.2478/v10078-011-0080-3

7. Cushion CJ, Armour KM, Jones RL. Coach education 
and continuing professional development: Experience and learning to coach. Quest. 2003;55(3):215- 30. https://doi.org/10.1080/00336297.2003.10491800

8. Serrano J, Shahidian S, Sampaio J, Leite N. The importance of sports performance factors and training contents from the perspective of futsal coaches. Journal of human kinetics. 2013;38:151- 60 . https://doi.org/10.2478/hukin-2013-0055

9. Moen F. The coach-athlete relationship and expectations. International Journal of Humanities and Social Science. 2014;4(11):29-40.

10.Smoll FL, Cumming SP, Smith RE. Enhancing coachparent relationships in youth sports: Increasing harmony and minimizing hassle. International Journal of Sports Science \& Coaching. 2011;6(1):13- 26. https://doi.org/10.1260/1747-9541.6.1.13

11.Turman PD. Coaches and cohesion: The impact of coaching techniques on team cohesion in the small group sport setting. Journal of Sport Behavior. 2003;26(1):86-92.

12.Côté J, Young B, North J, Duffy P. Towards a definition of excellence in sport coaching. International journal of coaching science. 2007;1(1):3-17.

13. Roxas AS, Ridinger LL. Relationships of Coaching Behaviors to Student-Athlete Well-Being. Academic Perspectives in Higher Education. 2016;2(1): 10-16. https://doi.org/10.32674/hepe.v2i1.21

14.Mottaghi M, Atarodi A, Rohani Z. The relationship between coaches' and athletes' competitive anxiety, and their performance. Iranian journal of psychiatry and behavioral sciences. 2013;7(2):68-75.

15.Siekańska M. Athletes' perception of parental support and its influence in sports accomplishments-a retrospective study. Human movement. 2012;13(4):380- 7. https://doi.org/10.2478/v10038-012-0046-x

16. Short SE, Short MW. Essay: Role of the coach in the coach-athlete relationship. The Lancet. 2005;366:S29- S30. https://doi.org/10.1016/S0140-6736(05)67836-1

17.Jagiello M, Iermakov SS, Nowinski M. Differentiation of the somatic composition of students physical education specialising in various sports. Archives of Budo Science of Martial Arts and Extreme Sports. 2017;13:63-70.

18.Kriventsova I, Iermakov S, Bartik P, Nosko M, Cynarski WJ. Optimization of student-fencers' tactical training. IIdo Movement for Culture-Journal of Martial Arts Anthropology, 2017;17(3):21-30. https://doi.org/10.14589/ido.17.3.3

19.Jagiello W, Jagiello M, Kalina RM, Barczynski BJ, Litwiniuk A, Klimczak J. Properties of body composition of female representatives of the Polish national fencing team - the sabre event. Biology of Sport. 2017;34(4):401-6. https://doi.org/10.5114/biolsport.2017.70526

20.Bai N, Dana A. The relationship between coaching behaviors and athletes' burnout in Golestan province futsal super league players. Euro J of Exp Bio. 2013;3(6):111-4.

\section{Information about the authors:}

Syed Zia-UI-Islam: (Corresponding author) ; http://orcid.org/0000-0003-2294-9447: ziaulislamgr8@gmail.com: Department of Sport Sciences and Physical Education Gomal University D.I. Khan: Gomal University Dera Ismail Khan, 29220, Khyber Pakhtunkhwa, Pakistan.

Salahuddin Khan: http://orcid.org/0000-0002-7784-7678: drsalahuddinkhan@yahoo.com: Department of Sport Sciences and Physical Education Gomal University D.I. Khan: Gomal University Dera Ismail Khan, 29220, Khyber Pakhtunkhwa, Pakistan.

Alamgir Khan: http://orcid.org/0000-0003-4768-8407: alamgir1989@hotmail.com: Department of Sport Sciences and Physical Education Gomal University D.I. Khan: Gomal University Dera Ismail Khan, 29220, Khyber Pakhtunkhwa, Pakistan.

Samiullah Khan: http://orcid.org/0000-0002-7176-3326: samikhan9182@gmail.com: Department of Sport Sciences and Physical Education Gomal University D.I. Khan: Gomal University Dera Ismail Khan, 29220, Khyber Pakhtunkhwa, Pakistan.

Cite this article as:

Syed Zia-UI-Islam, Salahuddin Khan, Alamgir Khan, Samiullah Khan. Coaching and training as influential factor, affecting sport at universities level. Pedagogics, psychology, medical-biological problems of physical training and sports, 2019;23(3):145149.

https://doi.org/10.15561/18189172.2019.0306

This is an Open Access article distributed under the terms of the Creative Commons Attribution License, which permits unrestricted use, distribution, and reproduction in any medium, provided the original work is properly cited (http://creativecommons.org/licenses/by/4.0/deed.en).

Received: 05.04.2019

Accepted: 05.05.2019; Published: 29.06.2019 